\title{
Evaluasi Pelaksanaan DRL (Daytime Running Light) Di Ruas Jalan Wonogiri-Ngadirojo Km +3 Bulusulur
}

\author{
Adi Setya Gud ${ }^{1)}$ \\ 1) Fakultas Teknik, Program Studi Teknik Sipil, Universitas Veteran Bangun Nusantara, Sukoharjo, Jl. \\ Letjen S Humardhani, No.1, Jombor, Sukoharjo; Telp. 0271-593156. Email: adisetyagud@ gmail.com
}

\begin{abstract}
Abstrak
Pemerintah Kabupaten Wonogiri melakukan evaluasi dengan UU No. 22 Tahun 2009 tentang menyalakan lampu utama bagi sepeda motor pada siang hari DRL (Daytime Running Light) guna mengatasi tingginya angka kecelakaan lalu lintas di Kabupaten Wonogiri. Pada penelitian ini pengambilan data primer langsung pada lokasi penelitian di Jalan Raya Wonogiri-Ngadirojo Km +3 Bulusulur, dengan rentang waktu tertentu yang ditentukan yakni penelitian dilakukan pada siang hari seperti penerapan yang diberlakukan pada peraturan ini, penelitian dilakukan pada hari-hari atau jam sibuk; hari Senin-Sabtu, Jam 06.30 - 08.30 WIB, Jam 10.00-11.30 WIB, Jam 12.00-13.30 WIB, Jam 15.30-17.00 WIB. Hasil pengamatan survei kendaraan bermotor (roda dua) di Jalan Wonogiri-Ngadirojo Km +3 Bulusulur, Wonogiri, tingkat partisipasi UU No. 22 tahun 2009 yaitu kewajiban pengendara sepedamotor untuk menyalakan lampu pada siang hari DRL (Daytime Running Light) yakni sebesar 96,65\% (12.927 dari 13.375 kendaraan), dan yang tidak menyalakan lampu sebesar 3,35\% (448 dari 13.375 kendaraan). Kecelakaan di Jalan Wonogiri-Ngadirojo Km +3 Bulusulur, Wonogiri antara tahun 2010-2013 menunjukan kenaikan dan penurunan namun, setelah tahun 2013 mengalami penurunan yang cukup signifikan dari 61 menjadi 27 pada tahun 2017. Hal tersebut bisa diakibatkan oleh tingkat kesadaran pengguna kendaraan bermotor utamanya menyalakan lampu untuk meningkatkan kewaspadaan. Meningkatnya kesadaran DRL (Daytime Running Light) dari tahun 2010 sebesar 46,96\% menjadi 96,65\% tahun 2017, di ikuti penurunan angka kecelakaan di Jalan Wonogiri-Ngadirojo Km +3 Bulusulur, Wonogiri dari 64 kejadian pada tahun 2013 menjadi 27 kejadian pada tahun 2017.
\end{abstract}

Kata kunci: Daytime Running Light, kecelakaan, sepeda motor

\begin{abstract}
Wonogiri Regency Government evaluated with Law no. 22 of 2009 concerning turning on the main lights for motorbikes during the daytime DRL (Daytime Running Light) to overcome the high number of traffic accidents in Wonogiri Regency. In this study, primary data collection was carried out directly at the research location on Jalan Raya Wonogiri-Ngadirojo Km +3 Bulusulur, with a specified period, namely the research was carried out during the day, such as the application of this rule, the research was carried out on days or days. busy time; MondaySaturday, 06.30 - 08.30 WIB, 10.00-11.30 WIB, 12.00-13.30 WIB, 15.30-17.00 WIB. The results of survey observations of motorized vehicles (two wheels) on Jalan Wonogiri-Ngadirojo Km +3 Bulusulur, Wonogiri, the level of participation of Law no. 22 of 2009, namely the obligation of motorcyclists to turn on the lights during the daytime DRL (Daytime Running Light), which is $96.65 \%$ (12,927 of 13,375 vehicles), and those who do not turn on the lights are $3.35 \%$ (448 of 13,375 vehicles). Accidents on Jalan Wonogiri-Ngadirojo Km +3 Bulusulur, Wonogiri between 2010-2013 showed an increase and decrease, however, after 2013 it decreased quite significantly from 61 to 27 in 2017. This could be caused by the level of awareness of vehicle users the main motor turns on the light to increase alertness. Increased awareness of DRL (Daytime Running Light) from 2010 by $46.96 \%$ to $96.65 \%$ in 2017, followed by a decrease in the number of accidents on Jalan Wonogiri-Ngadirojo Km +3 Bulusulur, Wonogiri from 64 incidents in 2013 to 27th invented in 2017.
\end{abstract}

Keywords: Daytime Running Light, accident, motorcycle

\section{PENDAHULUAN}

Kewajiban pada UU No. 22 tahun 2009 yaitu kewajiban pengendara sepedamotor untuk menyalakan lampu pada siang hari tepat pada pasal 107 ayat 2 yaitu "Pengemudi Sepeda motor selain memenuhi ketentuan sebagaimana dimaksud pada ayat (1) wajib menyalakan lampu utama pada siang hari”. Dengan adanya pasal tersebut, mewajibkan pengendara sepedamotor untuk menyalakan lampu kendaraannya pada siang hari.

Jalan di Kabupaten Wonogiri merupakan penunjang bagi penduduk dalam melakukan aktifitas dan sarana untuk meningkatkan perekonomian terutama yang berakibat pada peningkatan aktifitas dan kepadatan penduduk. 
Hal ini menuntut pelayanan jasa angkutan yang memadai bagi masyarakat. Angkutan umum yang ada belum dapat memberikan pelayanan yang maksimal (nyaman dan aman), maka penggunaan kendaraan pribadi masih diminati terutama sepeda motor. Meskipun dari pihak Kepolisian Kota Wonogiri telah melakukan sosialisasi di berbagai tempat adanya peraturan UU No. 22 Tahun 2009 khususnya pada pasal 107 ayat 2 yaitu kewajiban menyalakan lampu utama bagi sepeda motor pada siang hari. Namun masalah kecelakaan ini tidak dapat dihindarkan lagi, mengingat masih kurangnya kesadaran dan kepatuhan dalam bersepeda motor.

Willian Haddon mengembangkan konsep dimana faktor-faktor tersebut berinteraksi dalam suatu periode waktu tertentu. Penerapan pemodelan kecelakaan lalu lintas dibagi menjadi tiga fase waktu, yaitu sebelum kecelakaan (pre-crash), saat kecelakaan (crash), dan setelah kecelakaan (post-crash). Konsep inilah yang digunakan untuk menilai cidera (O`neil, 2002).

Manusia sebagai pengendara memiliki faktorfaktor yang mempengaruhi dalam berkendara, yaitu faktor psikologis dan faktor fisiologis. Keduanya adalah faktor dominan yang mempengaruhi manusia dalam berkendara di jalan raya. Faktor psikologis dapat berupa mental, sikap, pengetahuan, dan ketrampilan. Sedangkan faktor fisiologis mencakup penglihatan, pendengaran, sentuhan, penciuman, dan sistem syaraf (Notoatmojo, S, 2005).

Sepedamotor dapat diklasifikasikan berdasarkan tujuan penggunaannya menjadi 4 jenis sepeda motor (Dephub RI, 2006), yaitu sepeda motor harian, off-road, trail, dan roda tiga. Untuk mengendarai kendaraan bermotor juga diperlukan alat perlindungan diri (APD) bagi pengendara sepedamotor yang gunanya untuk meningkatkan keamanan dalam mengendarai sepedamotor, berikut adalah APD sesuai Departemen Perhubungan Republik Indonesia Derektorat jendral Perhubungan Darat (Dephub RI, 2004) yaitu helm, perlindungan mata dan wajah, sarung tangan, jaket, dan sepatu.

Untuk menciptakan suasana lalu lintas yang selamat, aman, cepat, lancar, tertib dan teratur, nyaman dan efisien perlu dukungan dari masyarakat Kabupaten Wonogiri selaku pihak yang dikenai kebijakan. Satuan Polisi Lalu Lintas Kabupaten Wonogiri memperlakukan UU tersebut guna mengatasi tingginya angka kecelakaan lalu lintas di Kabupaten Wonogiri, salah satunya melakukan evaluasi UU No. 22 Tahun 2009 menyalakan lampu utama bagi sepeda motor pada siang hari DRL (Daytime Running Light). Dengan adanya program tersebut pengguna sepeda motor Kabupaten Wonogiri diharapkan lebih waspada, sehingga dapat lebih berhati-hati dalam mengendarai sepeda motor di jalan raya.

Lampu DRL atau lampu kota pada dasarnya sama dengan model lampu lain, namun dalam segi intensitas cahaya lampu DRL tidak seterang low beam dan high beam. Mengingat lampu ini sebenarnya berfungsi untuk menginformasikan ke pengguna jalan lain bahwa dibelakang atau didepannya terdapat kendaraan. Dalam perkembangannya, lampu DRL mengalami perkembangan inovasi. Dulu lampu DRL masih menggunakan bolam sebagai pencahayaannya. Namun hal itu ternyata bersifat boros karena menghabiskan banyak energi baterai. Untuk itu, saat ini banyak pabrikan otomotif menggunakan LED DRL. Selain lebih sporty lampu LED dapat menekan penggunaan energi hingga 5 sampai 10 watt.

Menurut Iwan Ristanto (2010), tingkat partisipasi menyalakan lampu utama bagi sepeda motor pada siang hari DRL (Daytime Running Light) dijalan Wonogiri-Ngadirojo $\mathrm{Km}+3$ Bulusulur, masih cukup rendah yakni sebesar 46,96\% saja. Diharapkan dalam kurun waktu 8 tahun terdapat peningkatan partisipasi menyalakan lampu pada siang hari oleh pengendara motor dijalan Wonogiri-Ngadirojo $\mathrm{Km}+3$ Bulusulur Wonogiri.

Berdasarkan latar belakang sebelumnya tujuan dari penelitian yang dicapai adalah untuk melakukan evaluasi pelaksanaan UU No. 22 Tahun 2009 kususnya pada pasal 107 ayat 2 di jalan raya Wonogiri-Ngadirojo $\mathrm{Km}+3$ Bulusulur Wonogiri, mengetahui tingkat kecelakaan di jalan raya Wonogiri-Ngadirojo $\mathrm{Km}+3$ Bulusulur Wonogiri, serta untuk mengetahui pengaruh DRL (Daytime Running Light) terhadap angka kecelakaan di jalan raya Wonogiri-Ngadirojo $\mathrm{Km}+3$ Bulusulur Wonogiri?

\section{METODE}




\section{Metode}

Pemecahan masalah pada penelitian ini dengan menggunakan urutan kegiatan dalam memperoleh data dengan tahapan pengumpulan data, pengolahan, analisis data, dan cara pengambilan keputusan secara umum berdasarkan hasil pengamatan pada lokasi studi yakni di Jalan Raya Wonogiri-Ngadirojo Km +3 Bulusulur.

Tahap I dilakukan persiapan awal sebelum dimulai kegiatan penelitian diantaranya; perijinan dsb.

Tahap II dilakukan pencarian atau input data awal atau sekunder yang akan dipergunakan dalam penelitian diantarannya dari Polres Wonogiri dan pengamatan langsung pada lokasi yang akan diteliti yakni di Jalan Raya Wonogiri-Ngadirojo Km +3 Bulusulur.

Tahap III pengambilan data primer langsung pada lokasi penelitian di Jalan Raya WonogiriNgadirojo Km +3 Bulusulur, dengan rentang waktu tertentu yang ditentukan yakni penelitian dilakukan pada siang hari seperti penerapan yang diberlakukan pada peraturan ini, penelitian dilakukan pada hari-hari sibuk, atau jam sibuk; hari Senin-Sabtu, Jam 06.30 - 08.30 Wib, Jam 10.00-11.30 Wib, Jam 12.00-13.30 Wib, Jam 15.30-17.00 Wib.

Tahap IV dilakukan analisis terhadap data-data yang telah diperoleh dilapangan, diantaranya; Data Volume Kendaraan, Data random pengetahuan pengendara sepeda motor, dan data pengendara motor yang tertib aktif (berpartisipatif) melaksanakan UU Lalu lintas No. 22 Tahun 2009, kususnya penerapan pasal 107 ay at (2).

Sebagai pengukur jumlah dari arus lalu lintas digunakan "Volume". Volume lalu lintas menujukkan sejumlah kendaraan yang melintasi suatu titik pengamatan dalam satu satuan waktu (hari, jam,menit). Satuan volume lalu lintas yang umum dipergunakan adalah penentuan jumlah dan lebar jalur adalah :

(a) Lalu lintas harian rata-rata (LHR)

(b) Volume Jam perencanaan

(c) Kapasitas, kapasitas jalan adalah jumlah kendaraan maksimum yang dapat melewati suatu jalan pada jalur jalan selama 1 jam dengan kondisi serta arus lalu lintas tertentu. (Sukirman, 2002).
Tahap V pengambilan kesimpulan. Pada tahap ini, data yang telah dianalisa dibuat kesimpulan yang berhubungan dengan tujuan penelitian.

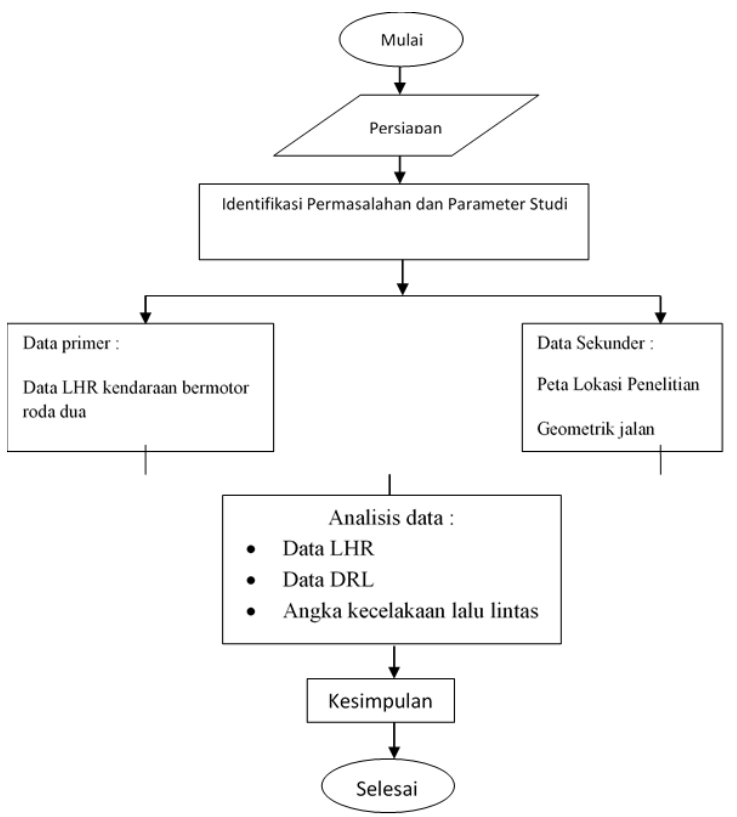

Gambar 1. Bagan Alir Penelitian

\section{Cara Pengambilan Data}

Data-data yang diperlukan untuk menganalisis kendaraan bermotor yang menyalakan lampu di siang hari:

1. Data volume ruas jalan lalu lintas setiap pada jam sibuk.

2. Data geometrik jalan (lebar dan jumlah jalur).

3. Data keadaan lingkungan dan tata guna lahan

di ruasjalan Wonogiri-Ngadirojo $\mathrm{Km}+3$ Bulusulur.

Pengumpulan data dilakukan di ruas jalan Wonogiri-Ngadirojo $\mathrm{Km}+3$ Bulusulur. Pada ruas jalan tersebut terdapat satu lajur. Waktu pengambilan data dengan menggunakan alat jam atau stopwatch dan alat tulis untuk mencatat volume kendaraan serta menghitung kendaraan bermotor yang menyalakan lampu sepeda motor dan yang mematikan lampu seprda motor di siang hari, survey lalu lintas dilakukan selama 7 hari.

Survey dilakukan pada jam-jam sibuk untuk masing-masing di ruas jalan WonogiriNgadirojo Km +3 Bulusulur yaitu :

1. Pagi hari antara pukul 06.00 sampai dengan 09.00 WIB

2. Siang hari antara pukul 12.00 sampai dengan 14.00 WIB 
3. Sore hari antara pukul 16.00 sampai dengan $18.00 \mathrm{WIB}$

\section{Metode penelitian}

Secara keseluruhan kegiatan penelitian ini dapat digambarkan kedalam bagan alir sebagai berikut

\section{HASIL DAN PEMBAHASAN}

Lokasi penelitian atau pengambilan data dilakukan di jalan Wonogiri-Ngadirjo $\mathrm{Km}+3$ Bulusulur, Wonogiri. Data kendaraan yang diambil adalah kendaraan bermotor yang menuju ke arah Ngadirojo atau Kota Wonogiri (dua jalur), sedangkan waktu yang dilakukan pada penelitian ini adalah pada waktu pagi sampai sore hari yakni seperti pada ketentuan peratuan UU Lalu Lintas No. 22 Tahun 2009 dimana kendaraan bermotor wajib menyalakan lampu pada siang hari (Daytime Running Light), yang bisa meningkatkan kewaspadaan bagi pengguna jalan yang berada di depannya.

Dari data lalu lalu lintas harian rata-rata seperti tampak pada Gambar 2, untuk kendaraan bermotor roda dua yang melintas di Jalan Wonogiri-Ngadirojo $\mathrm{Km}+3$ pada lajur kiri arah Wonogiri-Ngadirojo adalah sebesar 12.287 kendaraan dan pada lajur kanan arah NgadirojoWonogiri sebesar 11.341 kendaraan. Dari grafik 4.1 di atas dapat dilihat bahwa pada hari senin LHR kendaraan bermotor roda dua arah Wonogiri-Ngadirojo > dari pada arah Ngadirojo-Wonogiri, yakni 14.506>13375, sedangkan pada akhir pekan LHR kendaraan bermotor roda dua Wonogiri-Ngadirojo < dari pada arah Ngadirojo-Wonogiri, yakni $10.300<11819$.

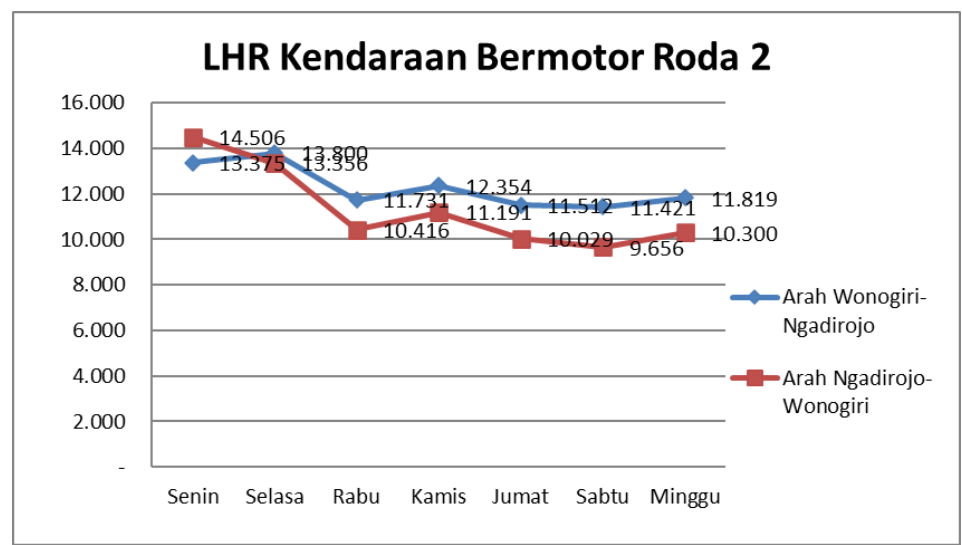

Gambar 2. Grafik Lalu Lintas Harian Rata-rata (LHR) Kendaraan Bermotor Roda Dua

\section{Volume Jam Puncak Kendaraan Bermotor Yang Menyalakan Lampu}

Jam puncak kendaraan bermotor roda dua yang melintas dua jalur jalan Wonogiri-Ngdirojo Km +3 Bulusulur, Wonogiri yang menyalakan lampu terbanyak atau tertinggi ditunjukkan oleh pengguna kendaraan bermotor pada pukul 06.00-07.00 Wib dan pukul 16.00-17.00, hal tersebut dimungkinkan karena situasi lingkungan yang masih gelap karena matahari masih rendah atau pada sore hari berkurangnya cahaya karena sinar matahari mulai tenggelam sehingga suasana lingkungan sedikit lebih gelap hal tersebut menuntut pengendara motor menyalakan lampu secara sadar, sedangkan tingkat partisipasi terendah ditunjukkan oleh pengguna kendaraan bermotor (roda dua) untuk menyalakan lampu pada pukul $12.00-13.00$ Wib, dikarenakan pada jam-jam tersebut adalah waktu dimana cahaya disekitar jalan dalam kondisi paling terang dan pengendara bermotor cenderung mematikan lampu kendaraannya. Dibawah inilah tingkat partisipasi tertinggi pengendara bermotor di jam-jam puncak pengendara di lajur kiri dan kanan.

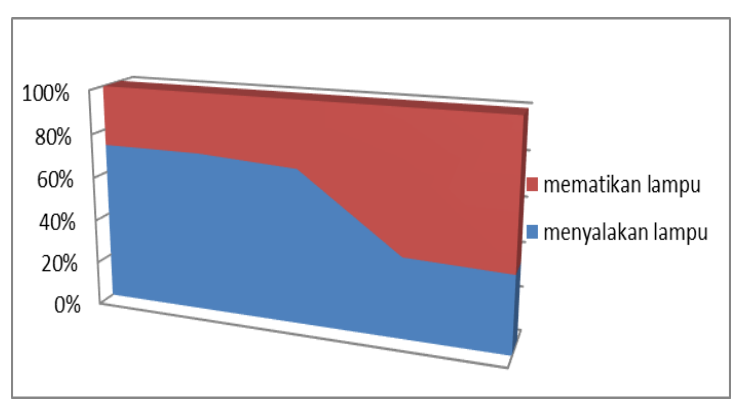

Gambar 3. lajur kiri tingkat partisipasi pengendara kendaraan bermotor (roda dua) untuk menyalakan dan mematikan lampu

Dilihat dari grafik pada Gambar 3 di atas pengendara bermotor roda dua yang melintas di Jalan Wonogiri-Ngadirojo $\mathrm{Km}+3$ tingkat 
partisipasi untuk menyalakan lampu lebih banyak dari pada kendaraan yang mematikan lampu.

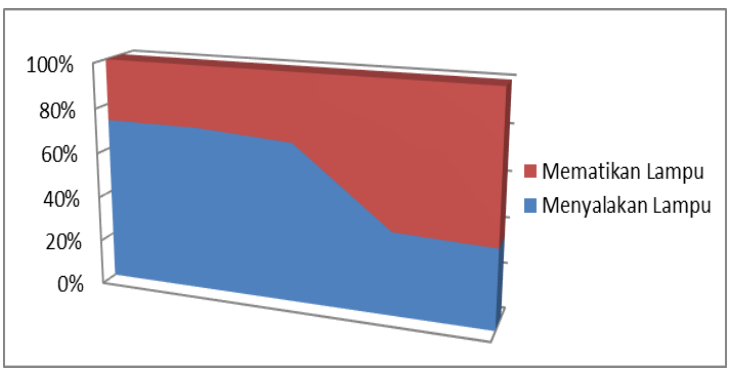

Gambar 4. lajur kanan tingkat partisipasi pengendara kendaraan bermotor (roda dua) untuk menyalakan dan mematikan lampu.

Dilihat dari Gambar 4 di atas pengendara bermotor roda dua yang melintas di Jalan
Wonogiri-Ngadirojo $\mathrm{Km}+3$ tingkat partisipasi untuk menyalakan lampu lebih banyak dari pada kendaraan yang mematikan lampu.

\section{Pengaruh DRL (Daytime Running Light) Terhadap Angka Kecelakaan}

Tujuan utama dibuatnya kebijakan DRL (Daytime Running Light) adalah untuk mengurangi atau menekan tingginya angka kecelakaan yang terjadi di jalan raya. Dengan melihat data kecelakaan dari Satlantas Polres Wonogiri, maka dapat diketahui jumlah kejadian kecelakaan selama 7 tahun kebijakan DRL (Daytime Running Light) diberlakukan sampai sekarang, kemudian dapat dianalisis apakah ada perubahan jumlah kejadian kecelakaan dari tahun 2010 seperti tampak pada Gambar 5.

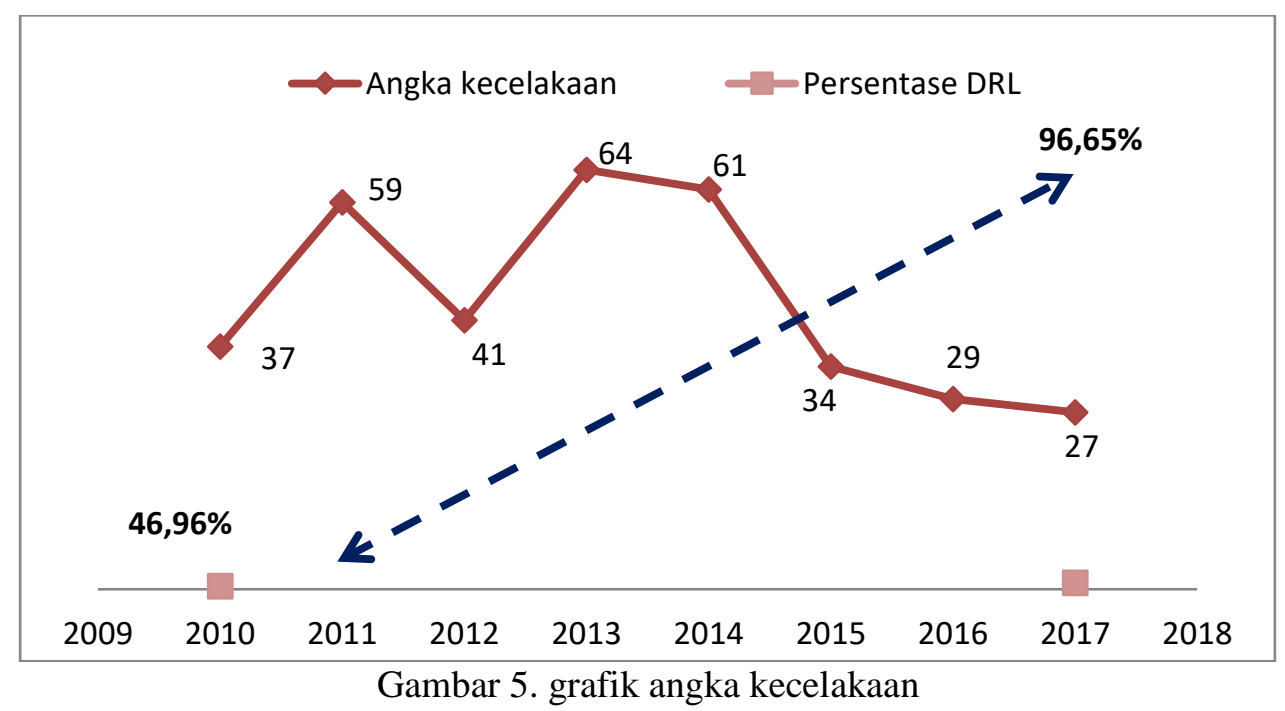

Dapat dilihat dari grafik angka kecelakaan dari tahun 2010-2017 angka kecelakaan menurun. Dapat dilihat pada Gambar 5, tingkat partisipasi menyalakan lampu utama bagi sepedamotor pada siang hari DRL (Daytime Running Light) di Jalan Wonogiri-Ngadirojo $\mathrm{Km}+3$ Bulusulur pada tahun 2010, masih cukup rendah yakni sebesar 46,96\% saja, sedangkan di tahun 2017 tingkat partisipasi menyalakan lampu utama sepedamotor yakni sebesar 96,65\% kendaraan. Terdapat peningkatan yang signifikan sebesar 49,69\% selama 9 tahun terakhir. Sedangkan tingkat kecelakaan di Jalan Raya WonogiriNgadirojo selama tahun 2010 sampai dengan 2017 secara umum terdapat penurunan jumlah angka kecelakaan terutama dari tahun 2014 sampai 2017.
Dengan terciptanya suasana tertib berlalu lintas yang baik antar sesama pengguna jalan, mustahil untuk mengurangi angka terjadinya kecelakaan lalu lintas di jalan raya secara signifikan. Setidak-tidaknya kita mulai dari diri kita sendiri seraya mengajak orang lain untuk ikut serta dalam mengamankan jalan raya yang semakin penuh sesak dengan kendaraan bermotor dari hari ke hari.

\section{SIMPULAN}

Berdasarkan hasil penelitian dan pembahasan yang telah dikemukakan maka dapat diambil kesimpulan bahwa tingkat partisipasi UU No. 22 tahun 2009 yaitu kewajiban pengendara sepedamotor untuk menyalakan lampu pada siang hari DRL (Daytime Running Light) yakni sebesar $\quad 96,65 \% \quad(12.927 \quad$ dari 13.375 
kendaraan), dan yang tidak menyalakan lampu sebesar 3,35\% (448 dari 13.375 kendaraan).

Kecelakaan di Jalan Wonogiri-Ngadirojo Km +3 Bulusulur, Wonogiri antara tahun 20102013 menunjukan kenaikan dan penurunan namun, setelah tahun 2013 mengalami penurunan yang cukup signifikan dari 61 menjadi 27 pada tahun 2017. Hal tersebut bisa diakibatkan oleh tingkat kesadaran pengguna kendaraan bermotor utamanya menyalakan lampu untuk meningkatkan kewaspadaan.

Meningkatnya kesadaran DRL (Daytime Running Light) dari tahun 2010 sebesar 46,96\% menjadi 96,65\% tahun 2017, di ikuti penurunan angka kecelakaan di Jalan Wonogiri-Ngadirojo $\mathrm{Km}+3$ Bulusulur, Wonogiri dari 64 kejadian pada tahun 2013 menjadi 27 kejadian pada tahun 2017.

\section{UCAPAN TERIMAKASIH}

Ucapan terima kasih terutama ditujukan kepada Prodi Teknik Sipil Univet Bantara yang membantu pelaksanaan penelitian

\section{DAFTAR PUSTAKA}

Dephub RI. 2006. Kriteria Teknis Kendaraan. www.Dephub.go.id (diakses pada tanggal 06 Desember 2017).
Dephub RI. 2004. Jenis Sepeda motor dan Alat perlindungan Diri Pengendara Sepedamotor. www.text-id.123dok.com. (diakses pada tanggal 06 Desember 2017).

Notoatmojo, S. 2005. Pendidikan dan Perilaku Pengendara. Jakarta: PT. Rineka Cipta.

O'neil, 2002. Faktor Yang Berhubungan Dengan Kecelakaan Lalu Lintas. www.Media.neliti.com. (diakses pada tanggal 06 Desember 2017).

Polres Wonogiri. 2017. Data Kecelakaan Lalu Lintas di Kabupaten Wonogiri. Wonogiri.

Republik Indonesia. 2009. Undang-Undang Republik Indonesia Nomor 22 Tahun 2009 Tentang .Lalu Lintas dan Angkutan Jalan. Jakarta.

Ristanto, Iwan. 2010. Tingkat Partisipasi Pengendara Sepedamotor di Jalan Raya Ngadirojo-Wonogiri Km 3 Bulusulur, Wonogiri. www.portalgaruda.com. (diakses pada tanggal 06 Desember 2017).

Sukirman, S. 2002. Dasar-dasar Perencanaan Geometri Jalan. Bandung : Penerbit Nova. 